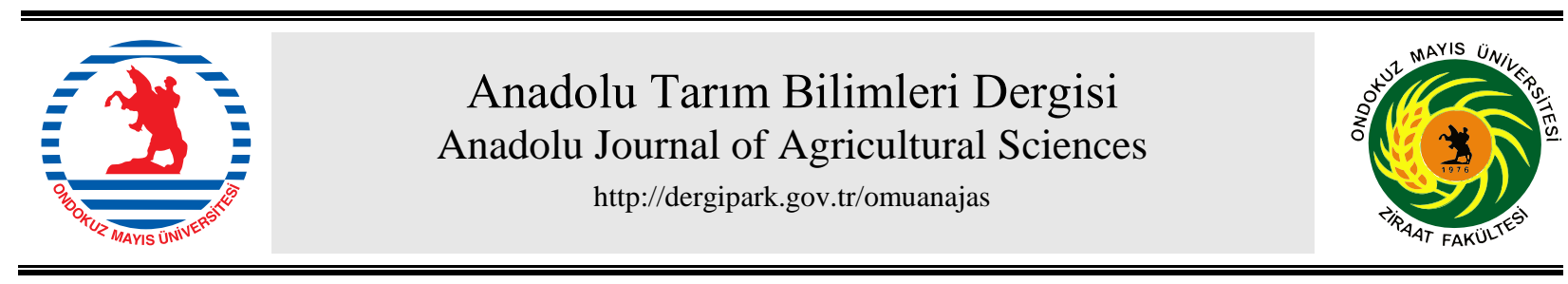

Araştırma/Research

Anadolu Tarım Bilim. Derg./Anadolu J Agr Sci, 36 (2021)

ISSN: 1308-8750 (Print) 1308-8769 (Online) doi: 10.7161/omuanajas.908552

\title{
Fındık tarımında çocuk işçiliği: Giresun ili Piraziz ilçesi örneği
}

\author{
๑Oğuzhan Karadeniz, @Erhan Akın, @Nur İlkay Abacı*
}

Ondokuz Mayıs Üniversitesi, Ziraat Fakültesi, Tarım Ekonomisi Bölümü, Samsun, Türkiye

*Sorumlu yazar/corresponding author: ilkaysonmez55@gmail.com

Geliş/Received 02/04/2021 Kabul/Accepted 10/07/2021

\begin{abstract}
ÖZET
$\mathrm{Bu}$ çalı̧̧manın amacı, Giresun ili findık hasadı döneminde tarım işçisi olarak çalıştırılan çocukların, yaşam koşullarının, fındık tarımında çalışmaya iten sosyo-ekonomik ve sosyo-kültürel etmenlerin ve barınma, beslenme, sosyal ihtiyaç ve gelecekle ilgili beklentilerinin belirlenmesi ve çocuk işçiliğinin önlenmesi konusunda bilinç oluşturulması için öneriler sunulmasıdır. Araştırmanın ana materyalini, Giresun ili Piraziz ilçesindeki findık işletmelerine çalışmak amacıyla gelen 66 çocuk iş̧̧i ile anket yapılarak elde edilen birincil veriler oluşturmuştur. Anket verileri 2019 yılı findık hasat zamanında elde edilmiştir. Anketlerden elde edilen birincil veriler, SPSS paket programına aktarılmış ve basit istatistik yöntemlerden frekans, yüzde, ortalama, minimum ve maksimum değerleri kullanılarak sonuçlar analiz edilmiş ve durum tespiti yapılmıștır. Giresun ili findık ișletmelerinde çalışan çocukların yaș ortalaması 15,89 olarak bulunmuştur. Çocuk işçilerde minimum çalışma yaş1 11 olarak tespit edilmiştir. Çocukların gelişimini sağlıklı bir şekilde tamamlamaları için en önemli yaşlarında olan çocuklar, sezon boyunca haftanın her gününde ortalama 10,33 saat çalışmaktadır. Araştırmada çocukların $\% 68,2$ 'sinin okula kayıtlı olduğu tespit edilirken, \%32,8'inin eğitim hayatına devam etmediği görülmüştür. Gelecekle ilgili beklentileri sorulduğunda, $\% 30$ 'u meslek sahibi olmak istediğini, \%18'i ezilmemeyi ve işçi olmak istemediğini ifade etmiş ve \%13,6'sının ise hiçbir beklentisinin olmadığı belirlenmiştir. Sonuç olarak, çocukken tarım iş̧̧isi olarak çalışmak ve mevsimlik tarım göçüne katılmak çocukları eğitim, sağlık, psikolojik gibi birçok açıdan olumsuzluklarla karşı karşıya bırakmakta ve gelişimlerini olumsuz yönde etkilemektedir. Bu durum da çocukların kaliteli yaşam hakkına engel olmaktadır. $\mathrm{Bu}$ nedenle ülke politikaları geliştirilirken tüm bunlar göz önünde bulundurulmalı, çocukların temel haklarının korunmasını garanti eden düzenlemeler geliştirilmeli ve uygulanmalıdır.
\end{abstract}

\section{Child Labor in Hazelnut Agriculture: Case of Giresun, Piraziz District}

\section{ABSTRACT}

This study aims to determine the living conditions, the socio-economic and socio-cultural factors that push them to work in hazelnut agriculture, and their housing, nutrition, social needs, and expectations for the future of the children who were employed as agricultural workers during the hazelnut harvest in Giresun province and suggestions are made to raise awareness on the prevention of child labor. The main material of the study was the primary data obtained by conducting a survey with 66 child workers who came to the hazelnut enterprises in Piraziz district of Giresun province to work. Survey data were obtained during the hazelnut harvest of 2019. The primary data obtained from the questionnaires were transferred to the SPSS package program and the results were analyzed and the situation was determined by using the frequency, percentage, average, minimum and maximum values from simple statistical methods. The average age of children working in the hazelnut enterprises in Giresun was found to be 15.89. The minimum working age for child workers has been determined as 11 . For children to complete their development healthily, children at their most crucial age work an average of 10.33 hours every day of the week throughout the season. In the research, it was found that $68.2 \%$ of the children were enrolled in school, while $32.8 \%$ did not continue their education life.

When asked about their expectations about the future, $30 \%$ stated that they wanted to have a profession,
Anahtar Sözcükler:

Çocuk

Fındık tarımı

Mevsimlik işçilik

Tarım işçisi

Keywords:

Child

Hazelnut farming

Seasonal labor

Agricultural worker

(C) OMU ANAJAS 2021 
$18 \%$ did not want to be oppressed and did not want to be a worker, and it was determined that $13.6 \%$ had no expectations. As a result, working as an agricultural worker as a child and participating in seasonal agricultural migration expose children to negative effects in many aspects such as education, health, and psychology. This situation hinders children's right to a quality life. For this reason, all these should be taken into account when developing country policies, and regulations that guarantee the protection of children's fundamental rights should be developed and implemented.

\section{Giriş}

Türkiye'nin önemli ve stratejik tarım ürünü fındık, ülkenin en önemli ihraç tarım ürünlerinin başında gelmektedir. Dünya fındık üretiminin yaklaşık \% 65-70'ini, ihracatının ise \% 70-75'ini karşılayan Türkiye dünyanın en önemli findık üreticisi ve ihracatçısı konumundadır. Türkiye'de yaklaşık 440 bin üretici, 700 bin hektar alanda fındık üretimi yapmaktadır (Anonim, 2019a). Türkiye'de 2019 yılında toplam 776.046 ton findık üretilmekteyken, aynı yıl dünya toplam findık üretimi 842.500 ton'dur (Anonim, 2019b). Dünyada toplam 976.200 ha findık dikim alanının 706.700 ha'ı Türkiye'de yer almakta olup, Türkiye'deki toplam findık dikim alanının yarısından fazlası (4.218.007 da) Doğu Karadeniz'de yer almaktadır. Giresun ili ise 1.171.903 da ile Doğu Karadeniz'in önemli findık üretim alanını oluşturmaktadır (Anonim, 2019b).

Türkiye'de findık işletmeleri genellikle küçük aile işletmeleri şeklinde olup, özellikle Doğu Karadeniz Bölgesi'nde yer şekillerinin de etkisiyle parçalı bir yapı göstermektedir. Fındık tarımı bölge halkı tarafından çoğunlukla ikinci iş/ek gelir olarak gerçekleştirildiği için, ortalama bir ay süren hasat döneminde iş gücü ihtiyacı, büyük ölçüde yerel iş̧̧ilerden karşılanamamakta, bu nedenle bölge mevsimlik göç almaktadır. Bu alanda istihdam genellikle mevsimlik olduğu için, tarım işçisi aileler sürekli ve yeterli gelir elde edememektedir. Bu nedenle tarım işçisi aileler yoksullukla karşı karşıya kalabilmektedir. Yoksulluğun sonuçları aile refahını olumsuz yönde etkilemekte ve en önemlisi ailede çalışmaya uygun olan herkesin özellikle çocukların çalışmak zorunda kalmalarıyla sonuçlanmaktadır.

Dünyada çalışan çocukların sayısı 2000 yılında 245 milyon iken, yıllar içinde azalma göstererek, 2016 yılı itibariyle yaklaşık 151.622.000 çocuk işçi bulunmaktadır. Çocuk işçiler, toplam çocuk nüfusunun \% 9,6'sına karşıllık gelmekte, çocukların yaklaşık 72.525 .000 'i, tehlikeli işlerde çalışmakta, bu rakam da dünya çocuk nüfusunun \% 4,6'sına karşılık gelmektedir. Çocuk işçilerin çalıştıkları alanlar incelendiğinde tarım, açık ara en önde gelen sektör olup, yaklaşık 108 milyon çocuk iş̧̧i bu alanda çalışmaktadır. Bu sayı toplam çocuk işçilerin yaklaşık \% 71'ini oluşturmaktadır (ILO, 2017; Gülcan, 2017).

Türkiye genelinde 5-17 yaş grubundaki çocuk sayısı 16 milyon 457 bin kişi olarak tahmin edilmiştir. 5-17 yaş grubunda bulunan çocukların \%4,4 ü (720 bin kişi) ekonomik olarak gelir getiren bir işte çalışmakta, çalışan çocukların \%79,7'sini 15-17, \%15,9'unu 12-14, \%4,4'ünü ise 5-11 yaş grubundaki çocuklar oluşturmaktadır. Cinsiyete göre incelendiğinde, istihdam edilen çocukların \%70,6'sını erkek, \%29,4'ünü ise kız çocukların oluşturduğu belirlenmiştir (TÜiK, 2020). Ekonomik işlerde çalışan çocukların \%30,8'i (221 bin kişi) tarım, \%23,7'si (171 bin kişi) sanayi ve \%45,5'i (328 bin kişi) hizmet sektöründe faaliyet göstermektedir. Çocukların \%66,0'ının düzenli işyerinde, \%30,4'ünün tarla-bahçede, \%3,0'ının sabit olmayan işyeri veya pazar yerinde çalıştı̆̆ belirlenmiş, \%0,5'inin ise evde çalıştığı tahmin edilmiştir (TÜiK, 2020).

İlik ve Türkmen'in (1994) ifade ettiğine göre; ailelerin sosyo-ekonomik durumu ve eğitim düzeyleri, çocukların iş hayatına girip girmemelerinde önemli rol oynamaktadır. Sağlıksız bir aile ortamında büyüyen çocuğun, eğitimine önem verilmemekte, aile bütçesine katkı sağlaması beklenmekte, çocuğun ruh ve beden sağlı̆̆ını tehlikeye atan işıerin yanı sıra, bağımlılığa neden olan işlerde (mobilya cilacısı, ayakkabı tamircisi vb.) çalıştırılmaktadır (Boybek, 2009).

Çocuklar fiziki ve ruhsal gelişimlerini sağlıklı bir şekilde sürdürme hakkına sahiptir. Çocuk işçiliği, özellikle tehlikeli boyutlardaki çocuk işçiliği, çocukların bu haklarının elinden alınmasına neden olmaktadır. Bu noktada çocuk işçiliği ve çocukların çalışması kavramları birbirine karıştırılmamalıdır. Çünkü çocuğun çalışması eğitimine engel olmamak kaydıyla ev işlerine yardım etmek, harçlığını çıkarmak için hafif işlerde çalışmak gibi yetişkinlik döneminde de sorumluluk almasına katkıda bulunan işleri kapsaması gerekirken; çocuk işçiliği, çocuğun fiziki ve ruhsal gelişimini olumsuz etkileyen, eğitimini aksatan işleri kapsamaktadır ve çocuğun yetişkinlik dönemini olumsuz etkilemektedir. "Çocuğun çalışması" ve "çocuk işçiliği”" birbirinden farklı kavramlar olmasına rağmen, uygulamada çoğu zaman birbirlerinin yerine kullanılmaktadır.

Uluslararası Çalışma Örgütü’nün (ILO) yaptığı tanıma göre; çocukların yaptıkları işlerin hepsi, ortadan kaldırılmak istenilen çocuk iş̧̧iliği kategorisine girmemektedir. ILO 182 no’lu En Kötü Biçimlerdeki Çocuk İş̧iliğinin Yasaklanması ve Ortadan Kaldırılmasına İlişkin Acil Eylem Sözleşmesi’nde, ortadan kaldırılması gereken çocuk iş̧̧iliği türleri belirlenmiştir. Türkiye bu sözleşmeye dayanarak Çalışma ve Sosyal Güvenlik Bakanlığı (ÇSGB) tarafindan hazırlanan Çocuk İşçiliğinin Önlenmesi İçin Zamana Bağlı Politika ve Program çerçevesinde tarımda çalışmayı, çocuk işçiliğinin en kötü biçimlerinden biri olarak belirlemiştir (Y1lmaz, 2017). 
Lordoğlu ve Etiler (2014), Batı Karadeniz bölgesinde mevsimlik gezici tarım işçiliğinde çalışan çocuklar üzerine bir araştırma gerçekleştirmiş ve araştırma bulgularına göre, çocukların her yıl eğitimlerinin yarıda kesildiğini ve onların okul başarısını olumsuz etkilediğini bildirmişlerdir. Bu olumsuz durumun, çocukları geleceğin mevsimlik işçileri haline getirdiğini, gezici mevsimlik tarım işçilerinin ise kötü yaşam koşullarından kaynaklı sağlık sorunları yaşadıklarını belirtmişlerdir.

Yılmaz (2017) "Giresun İli Fındık İşletmelerinde Çocuk İşçiliği”" isimli araştırmasından elde ettiği bulgulara göre, findık işletmelerinde çalışan çocukların yaş ortalamasının 14,8 olduğunu, günde ortalama 9,24 saat uygun olmayan şartlarda çalıştıklarını belirlemiştir. Ayrıca çocuk işçiliğinin öncelikle ailenin sosyo-ekonomik seviyesinin düşük olmasından kaynaklandığını bildirmiş̧ir. İşverenlerin \%68'inin işe alımda yaş sınırı gözetmediğini, işçilerin iş yapabilecek durumda olmasının işe alım kriteri olarak yeterli görüldüğünü belirlemiştir. Ayrıca, çocuk işçiliğini önlemek için Türkiye'nin taraf olduğu uluslararası hukuki düzenlemelerin uygulanması konusunda etkin denetimlerin yapılması ve caydırıcı boyutta yaptırımların uygulanması gerektiğini bildirmiştir.

Türkiye'de çocuk işçiliği konusunda bazı çalışmalar bulunmasına karşın, tarımda çocuk işçiliği konusunda yapılan çalışmalar yeterli değildir. Tarımda çocuk işçiliği sorununa dikkat çekmek için daha detaylı çalışmalara ihtiyaç vardır.

$\mathrm{Bu}$ çalışmanın amacı; Giresun ili fındık hasadı döneminde tarım işçisi olarak çalıştırılan çocukların yaşam koşullarının belirlenmesi, fındık tarımında çalışmaya iten sosyo-ekonomik ve sosyo-kültürel etmenlerin belirlenmesi, tarımda çalışan çocukların barınma, beslenme, sosyal ihtiyaç ve gelecekle ilgili beklentilerinin ortaya konması ve böylece çocuk işçiliğini önleme hususunda bilinç oluşturulması için öneriler geliştirmektir.

\section{Materyal ve Yöntem}

\subsection{Materyal}

Bu çalışmada Giresun ili, Piraziz ilçesindeki findık işletmelerinde çalışan 66 çocuk işçi ile yüz yüze görüşerek yapılan anket çalışmasından elde edilen veriler kullanılmıştır.

\subsection{Yöntem}

Giresun ili, Piraziz ilçesindeki findık işletmelerinde çalıştırılan çocuk sayısı konusunda güncel bir rakam bulunmamaktadır. Ancak ilçe jandarma komutanlığından alınan sözel bilgiler ve gidilen köylerde edinilen bilgiler 1şığında bütün çocuk işçilere ulaşılmaya çalışılmıştır. Anket yapılacak çocuk işçilerin belirlenmesinde tam sayım örnekleme yöntemi kullanılmış olup gönüllülük esasına göre 66 çocuk iş̧̧i ile yüz yüze anket çalışması gerçekleştirilmiştir. Araştırma kapsamında uygulanan anket formu; çocuk işçilerin sosyal ve demografik özelliklerini, aile bilgilerini ve yaşam şartlarını belirlemeye yönelik kapalı ve açık uçlu soruların yer aldığı üç bölümden oluşmaktadır. Anket verileri 2019 yılı findık hasat zamanında elde edilmiştir.

Anketlerden elde edilen birincil veriler, SPSS paket programına aktarılmış ve basit istatistik yöntemlerinden frekans, yüzde, ortalama, minimum ve maksimum değerleri kullanılarak analiz edilmiş ve durum tespiti yapılmıştır.

\section{Bulgular ve Tartışma}

Birleşmiş Milletler Çocuk Hakları Sözleşmesi uyarınca çocuklara uygulanabilecek olan kanuna göre, daha erken yaşta reşit olma durumu hariç, on sekiz yaşına kadar her birey çocuk sayılmaktadır. Çocuk Koruma Kanunu'na göre ise çocuk, daha erken yaşta ergin olsa bile on sekiz yaşını doldurmamış kişiyi ifade etmektedir (Resmi Gazete, 2005). Türkiye Çocuk İşü̈cü Anketi'nde ise 6-17 yaş arası bireyler çocuk olarak tanımlanmaktadır. Araştırma kapsamında ele alınan çocuk işçilerin yaşları incelenmiş ve minimum 11 maksimum 18, ortalama olarak ise 15,89 yaşında oldukları tespit edilmiştir. Çalışmaya dâhil olan çocukların sosyo-demografik özelliklerine ait bilgiler Çizelge 1'de verilmiştir.

Kırsal alanda artan nüfusa karşın değişmeyen tarım alanları, insanları farklı sektörlere ya da farklı tarım bölgelerindeki işlere yönlendirmektedir. Kısıtlı tarım alanlarının zorladığı kırsal nüfus mevsimsel olarak farklı tarım alanlarına göç ederek geçimini sağlamaktadır. Fındık tarımı işçilik isteyen bir tarım ürünü olması sebebiyle büyükküçük herkese iş imkânı sağlamaktadır. Araştırmada ele alınan çocuk işçilerin \%37,9'u Diyarbakır'dan, \%19,7'si Batman'dan ve \%15,2'si Siirt’ten gelmiştir. Genellikle findık hasadına gelen çocuk işçilerin Güneydoğu Anadolu Bölgesinden geldiği görülmektedir.

Fındık hasadına gelen çocuk işçilerin \%40,9'unun kız, \%59,1'inin ise erkek olduğu belirlenmiştir. Eğitim durumlarına bakıldığında \%68,18'inin okula devam ettiği, \%16,67'sinin ise mezun olduğu görülmektedir. Çocuk iş̧̧ilerin \%15,15'i okulu bırakmak zorunda kaldıklarını dile getirmişlerdir. Mezun olan çocukların \%45,5'i ortaokul, 
\%54,5'i lise mezunudur. Eğitimine devam eden çocuk iş̧ilerin \%2,2'si ilkokulda, \%26,7'si ortaokulda, \%68,9'u lisede ve $\% 2,2$ 'si üniversitede eğitim aldıklarını belirtmişlerdir. Türkiye'de ilkokul, ortaokul, lise ve üniversite şeklinde sıralı olarak ilerleyen bir sistemde öğrenciler çeşitli sebeplerden dolayı eğitimini yarıda bırakmak zorunda kalmakta veya kendisi okulu bırakmak istemektedir. Bu çalışmada okulu bırakan çocuk işçilerin \% 40 'ının ortaokuldan, \%60'ının ise liseden ayrıldığı tespit edilmiştir. Eğitime devam etmeme nedenleri incelendiğinde ise eğitime devam etmeyen çocukların \%33,3'ünün eğitim hayatlarında başarısızlık yaşadıklarından, \%33,3'ünün ise çalışarak aile bütçesine katkıda bulunmak istemelerinden dolayı eğitimlerine devam etmedikleri belirlenmiştir. Bununla birlikte anne ve babasının okula göndermediğini dile getiren ve kendi isteğiyle ayrılan çocukların olduğu da tespit edilmiştir. Kantar Davran ve ark., (2014), 7-14 yaş aralığındaki çocukların eğitimlerinden uzak kalmalarının, mevsimlik tarım işçiliğinin kuşaktan kuşağa aktarılmasını kolaylaştıran ve hızlandıran bir etmen olduğunu bildirmiştir. Bu nedenle bu yaş grubundaki çocuk işçilerin eğitimlerine önem verilmesi gerektiği aşikârdır. Ayrıca Uysal ve ark., (2016), mevsimlik tarım işçi çocuklarının temel eğitim sorunlarına yönelik önlemler ve düzenleyici kamu politikaları ile 2010 yılından itibaren bazı ilerlemeler görülmesine rağmen, çocukların eğitime erişim ve devam sorunlarına yönelik müdahale ihtiyacının sürdüğünü bildirmiştir.

\section{Çizelge 1. Çocukların sosyo-demografik özelliklerine ait bilgiler}

Table 1. Information on the socio-demographic characteristics of children

\begin{tabular}{|c|c|c|c|c|c|}
\hline Yaşanılan İl & $\mathrm{n}$ & Yüzde (\%) & Cinsiyet & $\mathrm{n}$ & Yüzde $(\%)$ \\
\hline Adiyaman & 2 & 3,0 & $\mathrm{~K} 1 \mathrm{z}$ & 27 & 40,9 \\
\hline Batman & 13 & 19,7 & Erkek & 39 & 59,1 \\
\hline Diyarbakır & 25 & 37,9 & Eğitim Durumu & $\mathrm{n}$ & Yüzde (\%) \\
\hline Gaziantep & 2 & 3,0 & Okula Devam Edenler & 45 & 68,18 \\
\hline Giresun & 1 & 1,5 & Eğitimi Bırakanlar & 10 & 15,15 \\
\hline Mardin & 7 & 10,6 & Mezun Olanlar & 11 & 16,67 \\
\hline Siirt & 10 & 15,2 & $\begin{array}{l}\text { Eğitime Devam Edenlerin } \\
\text { Bulunduğu düzey } \\
\end{array}$ & $\mathrm{n}$ & Yüzde (\%) \\
\hline Şanlıurfa & 6 & 9,1 & İlkokul & 1 & 2,2 \\
\hline Okula Gitmeme Nedenleri & $\mathrm{n}$ & Yüzde (\%) & Ortaokul & 12 & 26,7 \\
\hline 1. Çalışarak aile bütçesine katkıda bulunmak & 7 & 33,3 & Lise & 31 & 68,9 \\
\hline 2. Anne baba göndermedi & 1 & 4,8 & Üniversite & 1 & 2,2 \\
\hline 3. Başarısızlık & 7 & 33,3 & $\begin{array}{l}\text { Eğitimi Bırakanların } \\
\text { Eğitim Düzeyi } \\
\end{array}$ & $\mathrm{n}$ & Yüzde $(\%)$ \\
\hline 4. Diğer nedenler & 2 & 9,5 & $\begin{array}{l}\text { Ortaokul Mezunu } \\
\text {. }\end{array}$ & 5 & 23,81 \\
\hline 5. Kendi tercihi & 1 & 4,8 & Ortaokul terk & 4 & 19,05 \\
\hline 6. 1. ve 2. nedenler & 1 & 4,8 & Lise Mezunu & 6 & 28,57 \\
\hline 7. Fikri yok & 2 & 9,5 & Lise Terk & 6 & 28,57 \\
\hline
\end{tabular}

Çalışmaya dâhil olan çocuk işçilerin çalışmak için kiminle ve kimin aracılığıyla geldikleri, sosyal güvenceleri ve gelirlerini paylaşma durumlarına ait bilgiler Çizelge 2'de verilmiştir.

Araştırmada ele alınan çocuk işçilerin \%77,3'ü ailesiyle birlikte ve \%19,7'si tek başına findık hasadı için geldiğini belirtmiştir. Geri kalan \%3'ü ise kiminle geldiğine cevap vermemiştir. Araştırmada ele alınan çocuk işçilere, findık işçiliğine kimin aracılığı ile başladıkları sorulmuştur ve çocukların \%50,5'inin dayı başı, \%28,8'inin babası, \%6'sının annesi, \%3'ünün çavuş ve \%1,5'inin arkadaş aracılığıyla findık işçiliğine başladığı belirlenmiştir. Mevsimlik tarım işçisi olarak farklı illere göç eden aileler genellikle dayı başı aracılığıyla bölgelere gelmektedirler. Dayı başlarının her yıl aynı işverene iş̧̧i getirdiği de araştırmacılar tarafindan alandan edinilen diğer önemli bir bulgudur. Aynı zamanda ailesi ile birlikte çalışmaya gelen çocuklar, işverenle daha önceki senelerde kurduğu samimiyetten dolayı aynı işverenin yanına çalışmak için gelmektedirler.

Karaman ve Yılmaz (2011) mevsimlik tarım işçiliğinde, işverenden dayı başı ve işçiye doğru emek talebi ve işçiden de dayı başı ve işverene doğru ücret ve iş güvencesi talebi olduğunu bildirmiştir. Çalışma bulgularımız bu durumu doğrular niteliktedir. Araştırmadaki mevsimlik tarım iş̧̧ilerinin birçoğunun düşük gelirli ve ortalama 5 kişilik kalabalık bir aile yapısının olduğu görülmektedir (Çizelge 3). Kalabalık aile yapısı geçim zorluğunu doğurmakta bu yüzden fiziki olarak çalışabilir durumda olan bütün aile bireyleri çocuklarda dâhil olmak üzere çalışmaktadırlar. Fındık hasadının çocukların yaz tatili dönemine denk gelmesi dolayısıyla ailenin bireyleri için 
bulundukları şehirle bağımlılığının kalmaması nedeniyle farklı illere tarım işçiliği için göç edilebilmektedir. Bu durumda birçok aile yaz döneminde farklı tarımsal faaliyetlerde işçi olarak çalışmaktadır.

Çizelge 2. Çocuk iş̧̧ilerin çalı̧̧mak için kiminle ve kimin aracıllğ̆yla geldikleri, sosyal güvenceleri ve gelirlerini paylaşma durumlarına ait bilgiler

Table 2. Information on whom and through whom child workers come to work, their social security, and information on sharing their income

\begin{tabular}{|c|c|c|c|c|c|}
\hline Kiminle geldi & $\mathrm{n}$ & Yüzde (\%) & $\begin{array}{l}\text { Ailede herkesin findık tarımında } \\
\text { çalışma durumu }\end{array}$ & $\mathrm{n}$ & Yüzde (\%) \\
\hline Aileyle birlikte & 51 & 77,3 & Hepsi çalışıor & 17 & 25,8 \\
\hline Tek başına & 13 & 19,7 & Hepsi çalışmıyor & 44 & 66,7 \\
\hline Cevap yok & 2 & 3,0 & Cevap yok & 5 & 7,6 \\
\hline Kimin aracılığ 1 ile başladı & $\mathrm{n}$ & Yüzde (\%) & Sosyal Güvence & $\mathrm{n}$ & Yüzde (\%) \\
\hline Dayı başı & 33 & 50,0 & Güvencesi Yok & 6 & 9,1 \\
\hline Anne & 4 & 6,1 & Genel sağlık sigortası & 1 & 1,5 \\
\hline Baba & 19 & 28,8 & SGK & 7 & 10,6 \\
\hline Arkadaş & 1 & 1,5 & Cevap yok & 52 & 78,8 \\
\hline Kendi isteği ile & 2 & 3,0 & Aileden Harçlık Alma Durumu & $\mathrm{n}$ & Yüzde (\%) \\
\hline Diğer & 7 & 10,6 & Alıyor & 26 & 39,4 \\
\hline Geliri paylaşma nedeni & $\mathrm{n}$ & Yüzde (\%) & Almiyor & 36 & 54,5 \\
\hline Aile bütçesine yardım & 43 & 68,25 & Cevap Yok & 4 & 6,1 \\
\hline Ailenin düzenli geliri olmaması & 7 & 11,11 & Geliri aile ile paylaşma & $\mathrm{n}$ & Yüzde (\%) \\
\hline Babaya vermek zorunda olması & 1 & 1,59 & Paylaşıyor & 63 & 95,5 \\
\hline Kendi eğitim masrafları için & 1 & 1,59 & Paylaşmıyor & 2 & 3,0 \\
\hline Cevap yok & 11 & 17,46 & Cevap Yok & 1 & 1,5 \\
\hline
\end{tabular}

Araştırmada ele alınan çocuk işçilere, ailelerindeki herkesin findık hasadında çalışıp çalışmadığı sorulmuş ve \%25,8'inin evet, \%66,7'sinin hayır cevabı verdiği belirlenmiştir. Hayır cevabı veren çocuklar, ailelerindeki her üyenin sağlıklı olmadığını, aynı zamanda her üyenin çalışma koşullarına dayanacak fiziki güce sahip olmadığını ve yapması gereken başka işlerinin olduğunu ifade etmişlerdir. Çocuk işçilere sosyal güvence durumu sorulduğunda büyük çoğunluğunun $(\% 78,8)$ cevap vermemesi bu konuda bilgi sahibi olmadıklarını göstermektedir. Benek ve Ökten (2011), Şanlıurfa'nın Hilvan ilçesinde mevsimlik tarım işçileriyle yapmış oldukları çalışmalarında işçilerin önemli bir kısmının yeşil kart dışında herhangi bir sağlık güvencesine sahip olmadıklarını bildirmişlerdir.

Çocuk işçilerin \%39,4'ü okul döneminde ailelerinden harçlık aldıklarını \%54,5'i ise almadıklarını belirtmiştir. Harçlık almayanlar ailelerinin maddi sıkıntıları olması nedeniyle düzenli harçlık alamadıklarını ifade etmişlerdir. Araştırma alanındaki aileler sahip oldukları ekonomik imkânlar düzeyinde çocukların eğitim faaliyetlerini destekleyebilmektedirler. Ailedeki kişi sayısı, gelir ve çalışma süreleri hakkındaki bilgiler Çizelge 3'de verilmiştir.

Çizelge 3. Ailedeki kişi sayısı, gelir ve çalışma süreleri hakkındaki bilgiler

Table 3. Information on the number of people in the family, income, and working periods

\begin{tabular}{lccccc}
\hline Değişkenler & n & Ortalama & Medyan & Minimum & Maksimum \\
\hline Ailedeki kişi sayısı & 51 & 5 & 5 & 2 & 10 \\
\hline Günlük alınan harçlık (TL) & 26 & 11,28 & 4,00 & 1 & 85 \\
\hline Günlük kazanç (TL) & 66 & 90,60 & 95,00 & 80 & 100 \\
\hline Diğer işlerden alınan ücret (günlük) (TL) & 22 & 73,8 & 70,0 & 33 & 100 \\
\hline Gelir elde edilecek işlerde çalışma süresi (gün) & 66 & 3 & 2 & 1 & 10 \\
\hline
\end{tabular}

Araştırmada ele alınan çocukların günlük çalışma bedeli ortalama 90,60 TL olarak tespit edilmiştir. Tarım işçilerinin aldığı ortalama ücret valiliğin belirlediği fiyat civarındadır (Çizelge 3). Araştırma alanındaki çocukların çalışıyor olmalarının en önemli sebeplerinden biri ailelerinin maddi sıkıntılarının olmasıdır. Bu nedenle çocukların büyük çoğunluğu $(\% 95,5)$ elde ettikleri geliri aileleri ile paylaşmaktadır. Çocukların $\% 68,25$ 'i aile bütçesine yardım için, \%11,11'i ailesinin düzenli geliri olmadığı için aileleriyle gelirlerini paylaştıklarını bildirmişlerdir (Çizelge 2). 
Çocuk işçilerin başka işlerden kazandıkları ücret ortalama 73,8 TL/gün olarak belirlenmiştir. Çocukların ortalama 3 yıldır gelir elde edebilecek bir işte çalıştıkları belirlenmiş̧ir. Araştırmada henüz fiziksel gelişimini tamamlamamış küçük bedenlerin yaptığı işler karşısında aldıkları ücretin düşük olduğu fakat ailelerine yardımcı olmak ve hayatlarını sürdürmek için çalışmak zorunda oldukları sonucuna varılmaktadır. Aynı zamanda kırsal kesimde çocuğun çalışması ucuz bir iş gücü olmakla beraber çocuğun yaşam şartlarına ayak uydurması ve işi öğrenebilmesi için gerekli görülmektedir. Bu nedenle aileler çocuklarının çalışmasına karşı çıkmamakta, hatta desteklemekte ve onları bu yönde eğitmektedirler.

Çizelge 4. Çocuk işçilerin çalışma, problem ve sağlıkla ilgili durumları

Table 4. Work, problem and health status of child workers

\begin{tabular}{|c|c|c|c|c|c|}
\hline Başka işte çalışma durumu & $\mathrm{n}$ & Yüzde (\%) & Çalışmaya izin verme & $\mathrm{n}$ & Yüzde $(\%)$ \\
\hline Evet & 22 & 33,3 & Evet & 62 & 93,9 \\
\hline Hayır & 44 & 66,7 & Hayır & 1 & 1,5 \\
\hline Hangi işte çalışıyor & $\mathrm{n}$ & Yüzde (\%) & Cevap yok & 3 & 4,5 \\
\hline Tarım ürünleri hasadı & 12 & 54,55 & Problem durumları & $\mathrm{n}$ & Yüzde $(\%)$ \\
\hline Karton toplama & 1 & 4,55 & $\begin{array}{l}\text { Çok uzun süre çalışıyorum ancak } \\
\text { düşük ücretle çalışıyorum }\end{array}$ & 39 & 59,1 \\
\hline Tekstil & 1 & 4,55 & $\begin{array}{l}\text { Çalışırken kendimi güvende } \\
\text { hissetmiyorum }\end{array}$ & 2 & 3,0 \\
\hline Mangal kömürü & 1 & 4,55 & $\begin{array}{l}\text { Yaptığımız işlerin bize uygun } \\
\text { olduğunu düşünmüyorum }\end{array}$ & 7 & 10,6 \\
\hline Garsonluk & 1 & 4,55 & Hepsi & 1 & 1,5 \\
\hline Serbest & 3 & 13,64 & Problemim yok & 4 & 6,1 \\
\hline Diğer & 3 & 13,64 & Ailemle & 1 & 1,5 \\
\hline Çalışırken izin verme & $\mathrm{n}$ & Yüzde (\%) & Cevap yok & 12 & 18,2 \\
\hline Evet & 60 & 90,9 & Yaptığ1 İş & $\mathrm{n}$ & Yüzde $(\%)$ \\
\hline Hayır & 5 & 7,6 & Çuval taşıma & 12 & 18,2 \\
\hline Cevap yok & 1 & 1,5 & Findik toplama & 54 & 81,8 \\
\hline Şiddete maruz kalma durumu & $\mathrm{n}$ & Yüzde (\%) & Kaza geçirme durumu & $\mathrm{n}$ & Yüzde $(\%)$ \\
\hline Hayır & 63 & 95,5 & Evet & 2 & 3,0 \\
\hline Cevap yok & 3 & 4,5 & Hayır & 62 & 94,0 \\
\hline \multirow{2}{*}{$\begin{array}{l}\text { Sağlık Merkezine rahat } \\
\text { ulaşma durumu }\end{array}$} & \multirow{2}{*}{$\mathrm{n}$} & \multirow{2}{*}{ Yüzde (\%) } & Cevap yok & 2 & 3,0 \\
\hline & & & İşten kaynaklı hastalık durumu & $\mathrm{n}$ & Yüzde $(\%)$ \\
\hline Evet & 37 & 56,1 & Evet & 2 & 3,0 \\
\hline Hayır & 25 & 37,9 & Hayır & 60 & 91,0 \\
\hline Cevap yok & 4 & 6,1 & Cevap yok & 4 & 6,0 \\
\hline Değişkenler & & $\mathrm{n}$ & Ortalama & & Maksimum \\
\hline Haftalık çalışma süresi (gün) & & 66 & 6,95 & & 7 \\
\hline Günlük çalışma süresi (saat) & & 66 & 10,33 & & 12 \\
\hline Dinlenme süresi (dk.) & & 60 & 87,50 & & 120 \\
\hline
\end{tabular}

Çocukların findık tarımı dışında başka bir işte çalışma durumları incelendiğinde; \%33,3'ünün başka bir işte çalıştığı, \%66,7'sinin ise çalışmadığı tespit edilmiştir. Başka işlerde çalışan çocukların bir kısmı eğitim hayatlarına devam edememektedir. Çocuk işçilerin çalışma alanları; tarım, sanayi ve hizmet sektörü olarak sınıflandırılabilmektedir. Çocuklar tarım sektöründe genellikle yaz döneminde hasat olunan ürünlerin işlerinde çalışmaktadırlar. Aileleri ile birlikte fındık tarımından başka, çay toplama, nohut, fasulye gibi ürünlerin bakımı vb. gibi işlerde $(\% 54,55)$ uzun saatler çalıştıııldıklarını dile getirmişlerdir. Tarım sektörü dışında; karton topladıklarını $(\% 4,55)$, garsonluk yaptıklarını $(\% 4,55)$, tekstil üretimi yapan iş yerlerinde çalıştıklarını $(\% 4,55)$ belirten çocukların olduğu da görülmektedir. Ailelerin çocukların çalışmalarına izin verme durumları incelendiğinde \%93,9'unun ailesinin izin verdiği, \%1,5'inin ailesinin izin vermediği belirlenmiştir. Küçük yaşta çalışma hayatına başlayan çocukların sürekli geçici işlerde çalışmalarından ve çalışma sürelerinin de belirsiz olmasından kaynaklı fiziksel olarak gelişimlerinin ve psikolojik durumlarının olumsuz etkilendiği düşünülmektedir. Çocuk işçiler çalışma ve barınma alanlarında psikolojik olarak farklı problemlerle karşılaşabilmektedir. Nitekim araştırma alanındaki çocuk 
işçilere problemleri olup olmadığı sorulduğunda; \%59,1'inin “çok uzun süre çalış1yorum ancak düşük ücret alıyorum", \%10,6'sının "yaptığımız işlerin bize uygun olmadığını düşünüyorum" ve \%3'ünün ise "çalışırken kendimi güvende hissetmiyorum" cevabı verdiği görülmektedir. Çocukların $\% 6,1$ 'i bir problemi olmadığını \%1,5'i ise aile ile problemlerinin olduğunu belirtmişlerdir. Araştırma bulguları incelendiğinde, çocuk işçilerin uzun süre düşük ücretli çalışma durumlarını problem olarak gördükleri görülmektedir. Özellikle gezici tarım işçileri olarak kendilerini yerel işçilerle mukayese ettiklerinde bu durumun adaletsiz olduğunu düşünmektedirler ve dolayısıyla önemli bir problem olarak görmektedirler. Çocukların findık tarımında yaptıkları işler incelendiğinde ise \%81,8'inin findık topladığı, \%18,2'sinin çuval taşıdığ 1 belirlenmiştir. Ayrıca bazıları findık topladıktan sonra tarladan çıkarken çuval taşıdıklarını ve bu nedenle çok yorulduklarını ifade etmiştir. Çocukların fındık hasadında herhangi bir iş kazası geçirip geçirmedikleri önemli bir konu olarak düşünülmektedir. Çocukların \%94,0’ü bu soruya hayır cevabı verirken, \%3'ü evet cevabı vermiştir. İş kazası geçiren çocuk işçiler, arazinin eğimli olması nedeniyle yuvarlanıp ayaklarını incittiklerini, daldan fındık toplarken dalın çarpması nedeniyle yüzlerinin çizildiğini, örümcek veya arı sokma gibi durumları yaşadıklarını dile getirmişlerdir. İşten kaynaklı herhangi bir hastalık geçirme durumları incelendiğinde; çocuk işçilerin \%3'ü çok sıcakta ve açık havada çalıştıkları için güneş çarpması geçirdiklerini ayrıca fındık çuvallarını taşırken bel ağrısı yaşadıklarını ifade etmişlerdir. Geri kalan çocuk işçiler ise findık hasadında herhangi bir hastalık yaşamadıklarını belirtmişlerdir. Ayrıca çocukların \%56,1'inin sağlık ocağına rahatlıkla ulaşabildiği, \%37,9'unun ise sağlık ocağına rahat ve kolay bir şekilde ulaşamadığı belirlenmiştir.

Fındık hasadında çalışan çocuklar, haftalık çalışma sürelerinin havanın durumuna göre değiştiğini dile getirmekle beraber minimum 6 gün maksimum 7 gün çalışmaktadırlar. Günlük çalışma süreleri incelendiğinde ise çocukların ortalama 10,33 saat çalıştıkları görülmektedir. Maksimum çalıştıkları süre ise 12 saat olarak tespit edilmiştir. Çalışırken dinlenmelerini izin verilip verilmediği sorusuna ise \%90,9'u dinlenebildiğini belirtmiştir. Geri kalan kısım ise, işverenlerin fındık toplama maliyetlerinin yüksek olması nedeniyle aldıkları ücreti hak etmeleri için çalışırken izin vermediklerini ifade etmişlerdir. Dinlenen çocukların ise minimum 60, maksimum $120 \mathrm{dk}$ ortalama ise $88 \mathrm{dk}$. dinlendikleri ortaya koyulmuştur.

Çocuk işçilerin barınma, kişisel ve beslenme ihtiyaçlarının karşılanma durumlarına ait bulgular Çizelge 5'de verilmiştir.

Çizelge 5. Çocuk işçilerin barınma, kişisel ve beslenme ihtiyaçlarının karşılanma durumu

Table 5. Status of meeting the shelter, personal and nutritional needs of child workers

\begin{tabular}{|c|c|c|c|c|c|}
\hline Kalınan Yer & $\mathrm{n}$ & Yüzde (\%) & Uyudukları yer & $\mathrm{n}$ & Yüzde $(\%)$ \\
\hline Çadır & 4 & 6,1 & Koltuk & 3 & 4,5 \\
\hline $\mathrm{Ev}$ & 42 & 63,6 & Yerde & 59 & 89,4 \\
\hline Barınak & 19 & 28,8 & Diğer & 4 & 6,1 \\
\hline Cevap yok & 1 & 1,5 & İçme suyu temin edilen yer & $\mathrm{n}$ & Yüzde $(\%)$ \\
\hline $\begin{array}{l}\text { Tuvalet ihtiyacının } \\
\text { karşılandığ } 1 \text { yer }\end{array}$ & $\mathrm{n}$ & Yüzde (\%) & Çeşme & 52 & 78,7 \\
\hline Bahçe & 17 & 25,8 & Şebeke suyu & 7 & 10,6 \\
\hline Tuvalet & 38 & 57,6 & Tarladan bir yerden & 1 & 1,6 \\
\hline Tuvalet - Bahçe & 8 & 12,1 & Cevap Yok & 6 & 9,1 \\
\hline Cevap yok & 3 & 4,5 & Kalınan yerde sıcak su imkânı & $\mathrm{n}$ & Yüzde $(\%)$ \\
\hline Çöplerin atıldı̆̆ yer & $\mathrm{n}$ & Yüzde (\%) & Evet & 28 & 42,4 \\
\hline Araziye & 7 & 10,5 & Hayır & 36 & 54,5 \\
\hline Çöp kovasına & 45 & 68,1 & Cevap Yok & 2 & 3,0 \\
\hline Çöpleri yakıyoruz & 14 & 21,2 & Yiyeceklerin Muhafaza edildiği yer & $\mathrm{n}$ & Yüzde $(\%)$ \\
\hline Öğle yemeği kime ait & $\mathrm{n}$ & Yüzde $(\%)$ & Buzdolab1 & 32 & 49,9 \\
\hline İşverene & 15 & 22,7 & Saklama kabı & 9 & 13,6 \\
\hline İşçiye & 49 & 74,2 & Sepet & 2 & 3 \\
\hline \multirow[t]{2}{*}{ Cevap Yok } & \multirow[t]{2}{*}{2} & \multirow[t]{2}{*}{3,0} & Diğer & 11 & 16,5 \\
\hline & & & Cevap Yok & 12 & 17,0 \\
\hline
\end{tabular}

Çizelge 5 incelendiğinde çocukların iş̧̧i olduğu sürelerde \%63,6'sının işverenlerin vermiş oldukları evlerde kaldığı, \%19'unun barınakta kaldığı ve \%6,1'ininde çadırlarda kaldığg belirlenmiştir. Çocukların \%89,4'ünün yerde uyudukları belirlenmişken, bunun sebebinin işverenlerin verdikleri evlerin boş, eşyasız olması ve diğer bir neden olarak da kalınan yerde insan sayısının fazla olması sebebi ile kendilerine yatak düşmemesi olarak ifade etmişlerdir. Çocukların \%4,5'i ise koltukta uyuduğunu belirtmiştir. Benek ve Ökten (2011) yaptıkları çalışmada mevsimlik 
işçilerin \%78,4’ünün çadırlarda kaldığını bildirmiştir. Kaya ve Özgülnar, (2015) mevsimlik çalışanların çoğunluğunun olumsuz şartlarda çadırlarda kaldığını bildirmiştir.

Çocukların \%57,6'sı tuvalette, \%25,8'i bahçede, \%12,1'i tuvalet ve bahçede tuvalet ihtiyaçlarını gidermektedirler. Anket yapılan çocuklarla yapılan görüşmelerde kalınan ev uzak olduğundan findık bahçesinde tuvalet ihtiyaçlarını giderdiklerini dile getirmişlerdir. Çalışmaya dâhil olan çocukların \% 78,7'si su ihtiyaçlarını bölgede çıkan kaynak sularının bir depo yapılarak eve ulaştırılması ile temin ettiklerini belirtmişlerdir. \%10,6'sı şebeke suyundan temin ettiklerini, \%1,6'sı tarladan çıkan kaynak suyunun her gün elle taşınması ile temin ettiklerini belirtmiştir. Çocukların \%54,5'i sıcak su imkânlarının olmadığını, bahçeden geldiklerinde dışarıda ateş yakarak kazanlarda kaynayan suyla yıkanma, çamaşır ve bulaşık yıkama ihtiyaçlarını giderdiklerini belirtmişlerdir. Çocukların \%42,4'ü ise sıcak su imkânlarının olduğunu belirtmiştir. Anket yapılan çocukların \%68,1'i çöplerini, çöp kovasına attıklarını belirtmişlerdir. \%21,2'si çöplerini yaktıkları belirtmişlerdir. Neden yaktıkları sorulduğunda ise çöplerini atacak çöp kovaları olmadığı için böyle bir yöntem seçtiklerini söylemişlerdir. $\% 10,5$ 'i ise çöplerini araziye attıklarını belirtmişlerdir.

Çocuklara çalıştıkları sürede öğle yemeklerinin kime ait olduğu sorusuna verdikleri cevaplar incelendiğinde çocukların \%74,2'sinin yemeklerin işçiye, \%22,7'sinin ise işverene ait olduğunu belirtmişlerdir. \%3'ü ise bu soruya cevap vermemiştir. Ayrıca öğle yemeğini kendi yapan işçilere, işveren tarafindan erzaklar getirilip, bu yemekleri hazırlayana ise günlük yevmiye verdiklerini belirtmişlerdir. Anket yapılan çocukların \%49,9'u yiyeceklerini buzdolabında muhafaza ettiklerini, \%13,6'sı saklama kaplarında muhafaza ettikleri cevabını vermiştir. Diğer cevabı verenler buzdolabı gibi imkânları olmadığından genelde çabuk bozulan yiyecekler yerine muhafazası daha kolay yiyecekler aldıklarını ve bunları yediklerini belirtmişlerdir. Kaya ve Özgülnar (2015), yapmış oldukları çalışmalarında mevsimlik tarım işçilerinin yeterli oranda sebze, meyve ve protein tüketemediklerini, öğün atladıklarını ve uygun ortamda ve şartlarda saklanmayan besinleri tükettiklerini belirtmiştir.

Araştırmaya dâhil olan çocuk işçilerin çalışmalarından dolayı okul hayatlarının etkilenme ve gelecekten beklentilerine ait bulgular Çizelge 6'da verilmiştir.

Çizelge 6. Çocukların okul hayatları hakkındaki düşünceleri ve gelecekten beklentileri

Table 6. Children's opinions about their school life and their expectations from the future

\begin{tabular}{lcc}
\hline Okul hayatının etkilenme durumu & $\mathrm{n}$ & Yüzde (\%) \\
\hline Etkilenmedi & 27 & 40,9 \\
Olumsuz etkilendi & 15 & 22,7 \\
Olumlu, derslerime çok çalışıyorum & 3 & 4,5 \\
Kararsızım & 21 & 31,9 \\
\hline Gelecekten beklentiler & $\mathrm{n}$ & Yüzde (\%) \\
\hline Ailemle birlikte huzurlu yaşamak & 5 & 7,5 \\
Böyle giderse hiçbir beklentim yok & 9 & 13,6 \\
Çalışıp çok para kazanmak & 8 & 12,12 \\
Çok güzel umutlarım var & 1 & 1,52 \\
Ehliyet alıp araba sürmek & 1 & 1,52 \\
Ezilmemek, işçi olmamak & 12 & 18,18 \\
İktisat bölümü mezunu olmak & 1 & 1,52 \\
Meslek sahibi olmak & 20 & 30,30 \\
Okuluma devam etmek & 6 & 9,09 \\
Savaşın olmadığı, ayrımcılığın olmadığı, tartışmaları olmadığı bir hayat istiyorum ve en & 1 & 1,52 \\
önemlisi sessiz sakin bir tahtalı evde ailem ile yaşamak istiyorum & 1 & 1,52 \\
Yapmış olduğum işten binlerce kişinin faydalanması & 1 & 1,52 \\
Yaptığım işten pek memnun değilim avukat olmak istiyorum. Aile kurup çocuklarım için & 1 & \\
iyi bir baba olmak istiyorum & &
\end{tabular}

Elde edilen bulgulara göre çocukların \%40,9'u findık hasat sezonunun yaz mevsiminde olduğu için eğitimlerini çok fazla etkilenmediğini belirtmişlerdir. \%22,7'i ise hasat sezonunun bir kısmının okulların açıldığı zamana denk gelmesi yüzünden dersleri kaçırdıklarından olumsuz etkilendiğini belirtmişlerdir. \%31,9'u ise bu konuda kararsız olduklarını belirtmişlerdir. \%4,5'i ise olumlu etkilendi cevabını verirken hayatın zorluklarını bu çalıştığı sürede gördüklerini bundan dolayı derslere daha fazla çalışmaları gerektiğinin farkına vardıklarını belirtmişlerdir. Ayrıca anket yapılan çocuk işçilere gelecekle ilgili beklentileri sorulduğunda, \%30'u meslek sahibi olmak istediğini, \%18'i 
ezilmemeyi ve işçi olmak istemediğini, \%12'si çalışıp çok para kazanmak istediğini, \%13,6'sının ise hiçbir beklentisinin olmadığı belirlenmiştir.

\section{Sonuç ve Öneriler}

Araştırma bulguları ve saha gözlemlerine dayanarak findık tarımında çocuk iş̧̧iliğini önleme ve ortadan kaldırma ile ilgili bazı öneriler bu bölümde yer almaktadır. Öncelikle Türkiye'nin taraf olduğu uluslararası hukuki düzenlemeler ve ülkemizdeki ulusal hukuki düzenlemelerin etkin bir şekilde uygulandığında bu sorunun büyük oranda çözülmüş olacağı düşünülmektedir. Bu nedenle yeni hukuki düzenlemeler yapmak yerine mevcut hukuki düzenlemelerin uygulanmaya konulması ve etkin bir denetimin yapılması için adımlar atılmalı ve bu düzenlemelere uyulmaması halinde caydırıcı boyutta yaptırımlar uygulanması kaçınılmaz olmalıdır. Uygulanması gereken cezai yaptırımlar net bir şekilde belirlenmeli ve kamu spotları vasıtasıyla halk bu konuda bilgilendirilmelidir.

Fındık tarımının Ağustos ayına denk gelmesi ve bu dönemde çocukların tatil dönemi olması sebebi ile tatildeki çocuklar zor şartlarda çalışarak aile bütçelerine katkı sağlamaktadır. Fındık toplamaya gelen çocuk işçiler genellikle güneydoğu bölgesinden gelmektedir. Bunu göz önünde bulundurarak güneydoğu bölgesinden gelen çocuk işçilerin zanaatkâr esnafların yanına (berber, marangoz, vs.) veya aileler mevsimlik işçi olarak göç etmek zorundaysa, yatılı çıraklık okullarına verilerek hem kendi eğitimleri hem de üretime katılmaları sağlanabilir. Bu durum İŞKUR aracılığıyla yürütülebilir ve çalışan çocukların sigortalanması ve işverenin sigorta primlerinde de indirim sağlanmasıyla işveren ve çalışacak çocuk için yeni bir fırsat sağlanabilir. Ayrıca mevsimlik tarım işçilerinin ikamet ettiği yerlerde istihdamı sağlanarak, ailelerin düzenli gelir sağlayacak iş kollarında çalışması, böylece çocukların da bu mevsimlik işçi göçünden kurtulması sağlanabilir. Ailelerin çocuk işçiliği konusunda hassasiyetle eğitilmesi ve göç zamanları denetlenmesiyle çocuk işçilerin olumsuz durumlarla karşılaşmasının en aza indirilmesi mümkün olabilir.

Mevsimlik işçi çalıştıran tarımsal faaliyet alanları için de bunun bir ihtiyaç olduğu göz ardı edilmemelidir. İki tarafı içine alan bir yaklaşım açısından, işçilerin ve ailelerinin geçici mevsimlik tarım işçiliği yaptıkları süreyi, asgari sağlıklı yaşam standartlarının oluşturulduğu koşullarda geçirebilmeleri sağlanmalıdır. Bu yaklaşım, birden fazla paydaşın sorumluluk üstlenmesini gerektirmektedir. Fındık gibi önemli ve her yıl belirli dönem dışardan işçilik gerektiren ürünlerde çalışan mevsimlik işçiler için, süreklilik kazanmış sağlıklı barınma, eğitim, güvenlik olanakları için yapılacak yatırımlar, gerektirdiği maliyet ve emeği karşılar değerde olacaktır.

Sonuç olarak çocukken mevsimlik tarım göçüne katılarak tarım işçisi olarak çalışmak, çocukları eğitim, sağlık, psikolojik gibi birçok açıdan olumsuzluklarla karşı karşıya bırakmakta ve gelişimlerini olumsuz yönde etkilemektedir bu da çocukların kaliteli yaşam hakkına engel olmakta hatta gelecek neslin hayatına da gölge düşürmektedir. Çocukların, diğer iyi eğitim almış ve kaliteli çocukluk geçiren akranları gibi çocukluk dönemlerini geçirmeleri her çocuğun hakkıdır. Fakat genellikle yoksulluk nedeniyle çocuklar bu haklarından yoksun bırakılmaktadır. Çocukların bu hakkının gözetilmesinde elbette ailenin rolü büyüktür ancak aileler yoksulluktan dolayı çocuklarını çalıştırmak zorunda kalmaktadır. Yoksulluk nedeniyle zorunlu çalıştırma dışında bazı aileler çocuklarını çalıştırmayı bir ev geçindirme yolu olarak görmektedirler, ailelerin bu algısının kırılmasında eğitimin rolü büyüktür. Ülke politikaları geliştirilirken tüm bunlar göz önünde bulundurulmalı, çocukların temel haklarının korunmasını garanti eden düzenlemeler getirilmelidir. Eğer doğru kararlar alınır ve etkili bir şekilde uygulanır ise çocuk iş̧̧iliği ile mücadelede önemli adımlar atılmış olacaktır.

\section{Teşekkür}

Araştırmayı desteklemeye değer bulan TÜBİTAK 2209-A Üniversite Öğrencileri Araştırma Projeleri Destek Programına teşekkür ederiz. Ayrıca sorularımıza içtenlikle ve sabırla cevap veren çocuk işçilere ve zamanını ayıran işverenlerine çok teşekkürler.

\section{Çıkar Çatışması}

Yazarlar çıkar çatışması olmadığını beyan etmektedir.

\section{Kaynaklar}

Anonim, 2019a. Fındık Raporu 2018 [çevrimiçi]. TMMOB Ziraat Mühendisleri Odas1, http://www.zmo.org.tr/genel/bizden_detay.php?kod=30070\&sube $=0$ (Erişim tarihi: 21.09.2019).

Anonim, 2019b. 2018 Yılı Fındık Raporu [çevrimiçi]. Ticaret Bakanlığ Esnaf, Sanatkarlar ve Kooperatifçilik Genel 
https://esnafkoop.ticaret.gov.tr/data/5d44168e13b876433065544f/5c41e34d540794faaa011bdfa3466ff3.pdf (Erişim tarihi: 12.01.2020).

Benek, S., Ökten Ş., 2011. Mevsimlik tarım işçilerinin yaşam koşullarına ilişkin bir araştırma: Hilvan ilçesi (Şanlıurfa) örneği. Gaziantep University Journal of Social Sciences, 10(2): 653-676.

Boybek, S., 2009. Sosyal yardım uygulamaları ve çocuk işçiliği arasındaki ilişki: Keçiören örneği. Uzmanlık tezi, T.C. Başbakanlık Sosyal Yardımlaşma ve Dayanışma Genel Müdürlüğü, Ankara, 144 s.

Davran, M. K., Sevinç, M. R., Seçer, A., 2014. Türkiye'de mevsimlik tarım iş̧̧isi çocuklar. XI. Ulusal Tarım Ekonomisi Kongresi 3-5 Eylül 2014., Erol Yayınc1lık, Cilt 3, 1184-1192. Samsun, Türkiye.

Gülcan, M.G., 2017. Çocuk işçiliği ve eğitim-öğretmen el kitabı. T.C. Aile, Çalışma ve Sosyal Hizmetler Bakanlığı Genel Yayın No:72.

ILO, 2017. Global Estimates of Child Labour-Results and Trends: 2012-2016, ILO, Cenevre

İlik, B. Türkmen, Z., 1994. Çocuk işçiliğinin temel nedenlerinden birisi olan iç göç araştırma projesi dokümanı, ILO Yayınları, Ankara.

Karaman, K., YILMAZ, A.S., 2011. Mevsimlik tarım işçileri ve enformel ilişkiler ağı: Giresun'da çalışan mevsimlik tarım işçileri üzerine bir araştırma. Zeitschrift für die Welt der Türken/Journal of World of Turks, 3(1): 211-226.

Kaya, M., Özgülnar, N., 2015. Mevsimlik (gezici/geçici) tarım işçilerinin iki yerleşim birimindeki yaşam koşulları ve sağlık durumlarına niteliksel bakış. Türkiye Halk Sağlığı Dergisi, 13(2): 115-126.

Lordoğlu, K., Etiler, N., 2014. Batı Karadeniz bölgesinde mevsimlik gezici tarım işçiliğinde çalışan çocuklar üzerine sınırlı bir araştırma. Çalışma ve toplum. 41(2): 115-134.

Resmi Gazate, 2005. Çocuk Koruma Kanunu. Resmi Gazete Tarihi: 15.07.2005, Resmi Gazete Sayıs1: 25876.

TÜIK, $2020 . \quad$ Çocuk işgücü anketi $\quad$ sonuçlari- $2019 . \quad$ [çevrimiçi], http://www.tuik.gov.tr/PreHaberBultenleri.do?id=33807 (Erişim tarihi: 16.05.2020).

Uysal, M., Sayılan, F., Yıldız, A., Türk, E., Türkmen, N., Korkmaz, N., 2016. Mevsimlik tarım işçilerinin çocuklarının temel eğitim sorunları. Ankara Üniversitesi Eğitim Bilimleri Fakültesi Dergisi. 49 (1): 183-201.

Yılmaz, M. 2017. Giresun ili findık işletmelerinde çocuk işçiliği. Yüksek Lisans Tezi, Akdeniz Üniversitesi, Fen Bilimleri Enstitüsü, Antalya. 